\title{
Sikap Etik Dokter Terhadap Pelayanan Kesehatan Tradisional
}

\author{
Agus Purwadianto ${ }^{\mathrm{I}, 2}$, Soetedjo ${ }^{\mathrm{I}, 3}$, R. Sjamsuhidajat ${ }^{\mathrm{I}}$ \\ ${ }^{\mathrm{I}}$ Majelis Kehormatan Etik Kedokteran Pengurus Besar Ikatan Dokter Indonesia \\ ${ }^{2}$ Departemen Ilmu Kedokteran Forensik dan Medikolegal, Fakultas Kedokteran Universitas Indonesia/Rumah Sakit Cipto Mangunkusumo \\ ${ }^{3}$ Departemen Neurologi, Rumah Sakit Umum Daerah Dr. Moewardi, Surakarta, Jawa Tengah
}

\author{
Kata Kunci \\ etika, herbal, jamu, kedokteran, \\ tradisional \\ Korespondensi \\ contact@ilmiah.id \\ Publikasi \\ (C) 2019 JEKI/ilmiah.id \\ DOI \\ I0.26880/jeki.v3ii.29 \\ Tanggal masuk: 20 Oktober 2018 \\ Tanggal ditelaah: I2 Januari 2019 \\ Tanggal diterima: 18 Januari 2019 \\ Tanggal publikasi: 26 Februari 2019
}

\begin{abstract}
Abstrak Pelayanan kesehatan tradisional adalah salah satu ciri budaya dan kearifan lokal Indonesia. Pada saat ini, sebanyak $69.6 \%$ orang Indonesia menggunakan pelayanan kesehatan tradisional, baik berupa ramuan maupun keterampilan. Dalam sistem kesehatan di Indonesia, pelayanan kesehatan tradisional sudah diakui dengan disahkannya undang-undang/peraturan dan pohon keilmuan Sistem Kesehatan Tradisional Indonesia (SISKESTRAINDO). Tenaga medis dan tenaga kesehatan tradisional sudah selayaknya bekerja secara sinergis dalam pelayanan kesehatan, sehingga dibutuhkan panduan mengenai sikap etik sebagai seorang tenaga medis. Pelayanan kesehatan tradisional yang murah, mudah, dan mujarab harus didukung karena memiliki manfaat besar bagi masyarakat. Di sisi lain, pelayanan kesehatan tradisional yang tidak memenuhi syaratsyarat tersebut, terlebih memberikan dampak buruk pada pasien, harus ditolak dengan tegas metode, klaim, dan prakteknya.
\end{abstract}

\begin{abstract}
Traditional medicine is one of Indonesian's biocultural diversity. Currently, $69.6 \%$ of households in Indonesia use traditional medicine, either in the form of herbal medicine or manual techniques. Indonesia has formally accepted traditional medicine by integrating it in law and creating tree of knowledge of traditional health system (SISKESTRAINDO). Both conventional and traditional medical society should be working in synergy, therefore we need an ethical guideline about how the conventional medical society should respond toward the traditional medical society. Inexpensive, accessible, and effective traditional medicine should be supported because of its huge benefit toward the society. On the contrary, those which are expensive, inaccessible, and ineffective should be rejected because of the risks posed to the society.
\end{abstract}

Di dunia, selain pelayanan kesehatan konvensional juga dikenal pelayanan kesehatan tradisional. World Health Organization (WHO) sendiri mengakui pelayanan kesehatan tradisionaldan mendukung melaluistrategi20142023 yang memiliki target untuk meningkatkan integrasi pelayanan kesehatan tradisional terhadap kebijakan nasional; meningkatkan keamanan, efikasi, dan kualitas dari pelayanan kesehatan tradisional; meningkatkan akses baik secara ketersediaan maupun harga dari pelayanan; serta meningkatkan penggunaan rasional pengobatan tradisional dalam usaha meningkatkan kualitas kesehatan secara umum. ${ }^{1}$ Dalam Sistem Kesehatan Nasional di Indonesia, pelayanan kesehatan konvensional sudah diakui dan mendominasi karena dijalankan oleh dokter, perawat, bidan, dan tenaga medis profesional lainnya. Sebuah tantangan saat ini adalah pelayanan kesehatan tradisional yang semakin kuat dengan diakuinya tenaga kesehatan tradisional sebagai salah satu tenaga kesehatan sesuai dengan Undangundang Nomor 36 Tahun 2014 tentang Tenaga Kesehatan dan tergabung dalam Majelis Tenaga Kesehatan Indonesia (MTKI) bersama tenaga kesehatan lain di luar dokter dan dokter gigi. ${ }^{2}$ Selain itu juga telah dipopulerkan 
saintifikasi jamu sesuai dengan Peraturan Menteri Kesehatan Nomor 3 Tahun $2010^{3}$ dan disahkannya pohon keilmuan Sistem Kesehatan Tradisional Indonesia (SISKESTRAINDO), ${ }^{4}$ serta ditunjuknya beberapa rumah sakit untuk melakukan pelayanan kesehatan tradisional. Pemerintah juga telah menugaskan direktorat pelayanan kesehatan tradisional di Kementrian Kesehatan untuk mengembangkan dan menata pelayanan kesehatan sebagai bagian dari sistem kesehatan nasional. Pelayanan kesehatan tradisional meliputi pelayanan jenis keterampilan, ramuan, dan kombinasinya. Sesuai Peraturan Pemerintah Nomor 103 Tahun $2014,{ }^{5}$ pemerintah berupaya pula untuk melindungi pelayanan kesehatan tradisional yang terbukti secara ilmiah menyehatkan masyaratkan dan secara bertahap disinergikan dengan budaya dan kearifan lokal yang berguna.

Berdasarkan Riset Kesehatan Dasar (RISKESDAS) tahun 2013, pengguna pelayanan kesehatan tradisional dalam rumah tangga di Indonesia mencapai $69.6 \%$ dengan $77.8 \%$ menggunakan keterampilan tanpa alat dan $49 \%$ menggunakan ramuan. ${ }^{6}$ RISKESDAS 2018 menunjukkan $98.5 \%$ pelayanan kesehatan dilakukan oleh penyehat tradisional, sedangkan 2.7\% dilakukan oleh tenaga kesehatan tradisional. $^{7}$

\section{Peran Pelayanan Kesehatan Tradisional}

Peran pelayanan kesehatan tradisional ditujukan kepada klien/pasien sebagai manusia yang terdiri dari dua sisi, yakni sisi sehat dan sisi sakit. Hal ini sejalan dengan pengertian manusia sebagai makhluk biopsikospiritososiokultural (BPSSK). Seperti namanya, sisi sehat (klien) adalah keadaan tubuh terbaik yang mungkin dicapai secara jasmani, kejiwaan dan sosial sesuai dengan pengertian WHO akan sehat. ${ }^{8}$ Sisi sakit (pasien) adalah saat seseorang memiliki sebuah sakit/penyakit tertentu yang menimbulkan penderitaan akibat penurunan produktifitas, kecacatan, atau bahkan kematian. Pelayanan sisi sehat dan sisi sakit perlu dilakukan bersama-sama untuk mencapai definisi sehat menurut WHO, dan terdiri atas pendekatan biomedik dan biokultural. Pelayanan kesehatan tradisional lebih menekankan pendekatan biokultural sesuai dan memandang manusia sebagai BPPSK dibandingkan dengan pengobatan konvensional. ${ }^{5}$ Relevansi saling memengaruhi pendekatan biomedik dan biokultural akan semakin dijumpai pada penanggulangan penyakit tidak menular yang hanya akan terkontrol secara efektif dan efisien melalui pengubahan perilaku hidup bersih dan sehat. Hal ini untuk menanggulangi penyakit tidak menular yang menurut RISKESDAS akan semakin banyak dijumpai karena bersumber dari perilaku manusia.

Di beberapa negara seperti Cina dan India, pelayanan kesehatan tradisional telah didampingkan dengan pelayanan kesehatan konvensional dan sama-sama diakui keberadaannya serta dapat menjadi pilihan dari masyarakat. ${ }^{1}$ Dalam pelayanan kesehatan tradisional integrasi, untuk menjaga sisi sehat klien, dokter dan tenaga kesehatan tradisional sebaiknya bekerja sama sesuai dengan keilmuannya masing-masing. Apabila suatu saat seorang klien menjadi sakit, maka demi keselamatan pasien, orientasi sisi sakit lebih diprioritaskan dan seharusnya ditangani oleh dokter. Dalam keadaan pasien masih sehat atau memiliki penyakit yang terkontrol dan tidak dalam keadaan gawat darurat, maka dokter dan tenaga kesehatan tradisional dapat bekerja sama di fasilitas pelayanan kesehatan.

Secara sederhana, kontinuum pelayanan kesehatan tradisional empirik, komplementer, integrasi dan pelayanan kesehatan konvensional dapat ditunjukkan seperti gambar 1 .

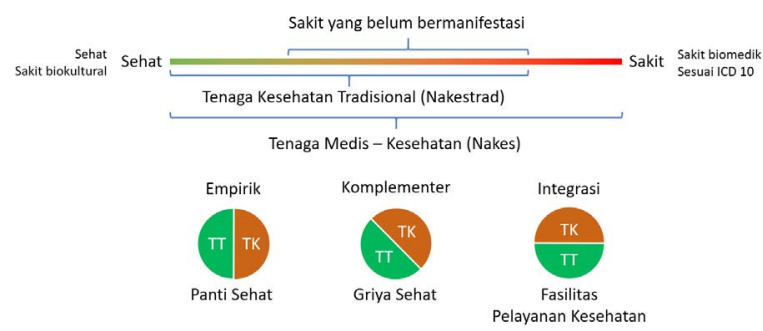

Gambar 1. Diagram pembagian peran pada kedua sisi.

\section{Jenis-jenis Pelayanan Kesehatan Tradisional}

Tenaga kesehatan tradisional dapat dibagi menjadi 3 jenis, yakni tenaga kesehatan tradisional empiris, komplementer, dan 
integrasi. Tenaga kesehatan tradisional empiris didefinisikan sebagai tenaga kesehatan tradisional yang ilmunya terbukti secara empiris, meliputi keterampilan dan/atau ramuan. Tenaga kesehatan tradisional empiris disebut sebagai penyehat tradisional. Tenaga kesehatan tradisional komplementer adalah tenaga kesehatan tradisional yang menggunakan ilmu biokultural dan biomedis, serta manfaat dan keamanannya terbukti secara ilmiah. Tenaga kesehatan tradisional komplementer dapat menggunakan moda teknik manual, terapi energi, terapi olah pikir, atau ramuan dari tanaman, hewan, mineral, maupun sarian khas Indonesia dengan tujuan meningkatkan indeks kebugaran. Tenaga kesehatan tradisional komplementer merupakan tenaga kesehatan yang memperoleh ilmu dan keterampilannya melalui pendidikan tinggi di bidang kesehatan paling rendah Diploma 3 yang saat ini sudah diakui kewenangan praktiknya melalui Peraturan Menteri Kesehatan Nomor 15 Tahun 2018 tentang Penyelenggaraan Pelayanan Kesehatan Tradisional Komplementer. ${ }^{9}$ Pelayanan kesehatan tradisional integrasi adalah kombinasi dari tenaga kesehatan selaku penanggung jawab dengan tenaga kesehatan komplementer. Pelayanan kesehatan tradisional integrasi harus diselenggarakan di fasilitas pelayanan kesehatan. ${ }^{5}$ Pemerintah saat ini berupaya untuk membuka pendidikan tinggi kesehatan tradisional Indonesia berbasis akademik profesional setingkat Sarjana 1 dan kelak lebih tinggi.

\section{Kesamaan Konsep Filosofis}

Perkembangan ilmu kedokteran di Indonesia saat ini dapat ditilik berdasarkan Undang-undang Nomor 20 Tahun 2013 tentang Pendidikan Kedokteran ${ }^{10}$ yang membagi ilmu kedokteran ke dalam empat pilar yaitu biomedik, klinis, kesehatan masyarakat, dan bioetika humaniora kesehatan. Kesamaan ilmu kedokteran konvensional dengan kesehatan tradisional akan mencakup keempat pilar tersebut, namun titik persamaannya lebih banyak di bioetika dan humaniora kesehatan. Secara ontologis paradigma konvensional mendefinisikan keadaan patologis sebagai sesuatu yang objektif (ditentukan oleh pemberi pelayanan terpisah dari persepsi pasien). Perkembangan mutakhirnya mengarah ke 4P medicine (personalized, preventive, predictive, dan participatory) yang ingin menjelaskan bahwa patologis objektif akan berinteraksi dengan subjektifitas pasien. Ini sejalan dengan konsep manusia sebagai BPSSK yang dianut oleh pelayanan kesehatan tradisional. Secara epistemologis cara pembuktian ilmiah konvensional menggunakan epidemiologi, uji klinik, dan luaran klinis yang bertumpu pada ukuran objektif, yang akan dilengkapi dengan pembuktian secara kuantitatif dan kualitatif berupa studi kasus, studi observasi klinis, penggunaan luaran klinis yang bersifat objektif. Dengan 4P, subjektivitas (patient reported outcome) dan kualitas hidup pasien akan menjadi penilaian bersama. Secara aksiologis, cara memakai ilmu kedokteran konvensional mengedepankan modalitas intervensi sebagai piranti penyembuhan yang lebih banyak berguna untuk penyakit akut dan gawat darurat. Sedangkan, pendekatan tradisional lebih mengedepankan interaksi utuh penuh kepercayaan (dyadic) antara penyembuh dan pasien dengan penguatan sisi sehatnya agar terjadi keseimbangan dan bahkan mengatasi sisi sakit pasien. ${ }^{4}$

Pelayanan kedokteran dengan konsep evidence-based medicine pada dasarnya lebih mengutamakan produk/standar yang diakui melalui hasil-hasil penelitian, sehingga seringkali terjadi produk/standar mengonstruksi pemberi layanan dan pasien sekaligus. Sedangkan, pada pelayanan kesehatan tradisional produk didesain berdasarkan kebutuhan bersama antara penyehat/tenaga kesehatan tradisional dengan klien sesuai kepentingan terbaik klien. ${ }^{4}$

\section{Sikap Dokter Terhadap Pelayanan Kesehatan Tradisional}

Dokter seharusnya memiliki pikiran positif dalam bekerja bersama dengan para tenaga kesehatan tradisional untuk mempertahankan sisi sehat seorang klien. Upaya ini sebenarnya selaras dengan tujuan preventif dan promotif seorang dokter dalam masyarakat. Selain itu, dokter seharusnya memahami bahwa pelayanan 
kesehatan tradisional adalah wujud salah satu ciri budaya dan kearifan lokal masyarakat yang harus dilestarikan, apalagi negara kita terkenal dengan biodiversitasnya, dan sekaligus dikembangkan. Selayaknya dokter berlaku bijak dan adil dalam menyikapi pendekatan biokultural untuk pelayanan penyakit-penyakit yang bersifat emik (didalilkan oleh komunitas setempat), apalagi bila secara konvensional tidak terdefinisikan dengan baik, contohnya adalah masuk angin atau panas dalam. Pelayanan kesehatan tradisional juga dapat menjadi salah satu sumber pendapatan masyarakatnya, berupa penggunaan dan pengolahan bahan jamu dan obat tradisional dari dalam negeri. Secara makro, bahan bakunya semestinya dari bahan alam dapat diolah menjadi produk berkhasiat skala rumah tangga atau skala industri sehingga akan menambah devisa negara. Pelayanan spa medik yang dilakukan dalam rangka pariwisata berpotensi menarik lapangan kerja sekaligus pemberi jasa tipe keterampilan bersama tipe ramuan. Di sisi lain, secara budaya masih terdapat fakta bahwa masyarakat penggemar jamu menjadi korban dan belum sepenuhnya terlindung dari pelayanan dan/atau penggunaan produk kesehatan tradisional, apalagi bila dicampur dengan bahan kimia obat.

Dalam menyikapi bercampurnya pelayanan konvensional dan pelayanan kesehatan tradisional, seorang dokter seharusnya memiliki beberapa pertimbangan yang dapat dijadikan patokan untuk menentukan etis tidaknya suatu pelayanan kesehatan tradisional:

1. Apabila suatu pelayanan kesehatan tradisional melakukan klaim kuratif terhadap penyakit-penyakit yang telah memiliki pengobatan baku emas dan terbukti secara nasional maupun internasional, termasuk dalam Pedoman Nasional Pelayanan Kesehatan (PNPK) atau Panduan Praktik Klinis (PPK), serta sudah diakui dan dibiayai oleh Jaminan Kesehatan Nasional (JKN). Contoh dari kasus ini antara lain lupus eritromatosus sistemik dan infeksi human immunodeficiency virus. Dalam hal ini, seorang dokter harus menolak dengan tegas klaim, metode, dan praktik pelayanan kesehatan tradisional tersebut.

2. Apabila suatu pelayanan kesehatan tradisional melakukan klaim kuratif terhadap penyakit-penyakit akut, bersifat gawat darurat, atau mengancam nyawa yang sebenarnya dapat diintervensi dengan sempurna secara medis, serta memiliki periode emas dalam pengobatannya, maka seorang dokter harus menentang dengan tegas atas dasar kepentingan pasien demi keselamatannya. Contoh dari kasus ini antara lain serangan jantung dan stroke. Dalam hal ini, seorang dokter harus menolak dengan tegas klaim, metode, dan praktik pelayanan kesehatan tradisional tersebut.

3. Apabila suatu pelayanan kesehatan tradisional melakukan diagnosis menggunakan alat diagnostik konvensional di luar kompetensinya. Contoh dari kasus ini antara lain seorang tenaga kesehatan tradisional memesan dan menginterpretasi sendiri hasil Computed Tomography (CT) scan atau Magnetic Resonance Imaging (MRI). Dalam hal ini, seorang dokter harus menolak dengan tegas klaim, metode, dan praktik pelayanan kesehatan tradisional tersebut.

4. Apabila suatu pelayanan kesehatan tradisional melakukan terapi menggunakan metode terapi konvensional di luar kompetensinya. Contoh dari kasus ini antara lain penggunaan obat golongan obat keras, psikotropika, atau bahkan narkotika yang memerlukan resep. Dalam hal ini, seorang dokter harus menolak dengan tegas klaim, metode, dan praktik pelayanan kesehatan tradisional tersebut.

5. Apabila ditemukan suatu pelayanan kesehatan tradisional berupa jamu atau ramuan yang dicampurkan dengan obatobatan konvensional atau disebut sebagai bahan kimia obat (BKO). Dalam hal ini, dokter harus menolak dengan tegas $\mathrm{BKO}$ yang dicampurkan tetapi tidak serta merta menolak jamu atau ramuan tradisional yang telah terbukti secara empirik.

6. Apabila suatu pelayanan kesehatan tradisional tidak memiliki bukti efektivitas, 
tidak murah, tidak mudah, atau mengklaim kompetensi yang dimiliki oleh praktik kedokteran. Contoh dari kasus ini antara lain menawarkan paket-paket pengobatan tradisional berbayar di muka, praktik multilevelmarketingyang tidakjelas khasiatnya, ataupun meminta tarif dengan harga yang eksploitatif sehingga dapat menimbulkan kerugian ekonomi pasien. Dalam hal ini, seorang dokter harus menolak dengan tegas klaim, metode, dan praktik pelayanan kesehatan tradisional tersebut.

7. Apabila suatu pelayanan kesehatan tradisional tidak sesuai dengan perizinan yang dimiliki sesuai dengan Peraturan Pemerintah (PP) nomor 103 tahun 2014 tentang Pelayanan Kesehatan Nasional. Penyehat tradisional yang hanya melakukan klaim atas promotif dan preventif harus memiliki Surat Terdaftar Penyehat Tradisional (STPT). Tenaga kesehatan tradisional yang melakukan klaim kuratif harus memiliki Surat Tanda Registrasi Tenaga Kesehatan Tradisional (STPTKT) dan Surat Izin Praktik Tenaga Kesehatan Tradisional (SIPTKT). Hal ini sama seperti seorang dokter harus memiliki Surat Tanda Registrasi (STR) dan Surat Izin Praktek (SIP) sebelum dapat melakukan praktek kedokteran. Dalam hal ini, seorang dokter harus menolak dengan tegas klaim, metode, dan praktik pelayanan kesehatan tradisional yang tidak berizin tersebut. ${ }^{5,10}$

8. Apabila suatu pelayanan kesehatan tradisional melakukan klaim yang berlebihan, belum diterima oleh masyarakat kedokteran dan/atau kesehatan karena manfaat dan keamanannya diragukan atau belum terbukti. Dalam hal ini, seorang dokter harus menolak dengan tegas klaim, metode, dan praktik pelayanan kesehatan tradisional tersebut. ${ }^{12}$

9. Apabila suatu pelayanan kesehatan tradisional melakukan klaim kuratif secara biokultural terhadap penyakit yang tidak berbahaya, tidak darurat, dan tidak ada baku emas pengobatannya, contohnya masuk angin dan panas dalam, dalam hal ini seorang dokter berlapang dada menerima pelayanan kesehatan tradisional tersebut, dengan cara mendukung saintifikasi dan bila terbukti efektif mendorong pemakaiannya dan memasukkannya ke dalam indikasi medis serta bila perlu masuk ke dalam JKN.

10. Apabila suatu pelayanan kesehatan tradisional mudah, murah, dan mujarab, terutama pelayanan kesehatan tradisional yang menggunakan metode-metode yang khas Indonesia dengan memanfaatkan sumber daya alam Indonesia sehingga memiliki kekhususan tersendiri. Dokter harus menerima dan mendukung pelayanan kesehatan tradisional tersebut karena selain bermanfaat tetapi juga memiliki nilai jati diri, ekonomi, sosial, budaya, sebagaimana sudah dicanangkan pemerintah dalam Undang-undang Nomor 5 Tahun 2017 tentang Pemajuan Budaya. ${ }^{13}$

11. Seorang dokter harus menghormati pilihan pasien apabila memang ingin menggunakan obat-obatan yang tergolong / jenis pelayanan yang tergolong dalam obat tradisional dengan cara yang bijak dan tidak mencela teman sejawat yang memang mendalami dan dengan menggunakan pendekatan ekletik holistik untuk kepentingan terbaik pasien, mengembangkan kesehatan tradisional dengan etikat baik untuk memajukan bangsa, mencegah ketergantungan obat ataupun alat kesehatan dari luar negeri serta untuk kepentingan promotif dan preventif.

12. Seorang dokter terdorong untuk mensupervisi sesama tenaga kesehatan khususnya tenaga kesehatan tradisional dalam interkolaborasi mengusung paradigma sehat (gerakan masyarakat sehat, Perilaku Hidup Bersih Sehat, dan mengentaskan kemiskinan) sebagai sumber dari rendahnya derajat/status kesehatan masyarakat.

Dokter dan pelayanan kesehatan tradisional sebaiknya bekerja sama dengan membuat sebuah tempat terlokalisir atau kordinasi secara regional agar dapat memudahkan proses supervisi, edukasi, konsultasi, dan penelitian. Proses supervisi artinya praktik pelayanan kesehatan tradisional harus dalam batas yang sesuai dengan kemampuannya, tidak melakukan klaim-klaim 
atau tindakan yang tidak sesuai kompetensi sesuai perizinannya. Proses edukasi artinya dilakukan pelatihan agar praktik pelayanan kesehatan tradisional semakin terstandardisasi, tidak membahayakan, serta para tenaga kesehatannya dapat mengidentifikasi kemungkinan adanya penyakit yang berada pada ranah konvensional. Proses konsultasi artinya tenaga kesehatan tradisional dapat berkonsultasi dengan dokter dengan mudah ketika menemukan suatu kasus yang rancu. Proses penelitian adalah proses saintifikasi suatu metode pelayanan kesehatan tradisional sehingga nantinya dapat dibuktikan secara evidence-based medicine.

\section{KESIMPULAN}

Pengobatan konvensional dan tradisional harus bekerja secara sinergis dan sesuai porsinya dengan memperhatikan kondisi dari klien atau pasien. Dokter harus menyadari kalau pengobatan tradisional adalah salah satu kekayaan budaya dan berpotensi secara ekonomi. Dokter juga selayaknya dapat membuat keputusan apakah suatu pengobatan tradisional adalah etis atau tidak dengan kaidahkaidah yang sesuai. Bentuk kerjasama yang dapat dilakukan antara seorang dokter dengan pengobat tradisional antara lain dalam hal supervisi, edukasi, konsultasi, dan penelitian.

\section{KONFLIK KEPENTINGAN}

Tidak ada konflik kepentingan.

\section{REFERENSI}

1. World Health Organization. WHO traditional medicine strategy: 2014-2023. Hong Kong: WHO Press; 2013.

2. Undang-undang Nomor 36 Tahun 2014 tentang Tenaga Kesehatan.

3. Peraturan Menteri Kesehatan Nomor 3 Tahun 2010 tentang Saintifikasi Jamu.

4. Siswanto. Pengembangan kesehatan tradisional Indonesia: konsep, strategi, dan tantangan. Jurnal Penelitian dan
Pengembangan Pelayanan Kesehatan. 2017; $1(1): 17-31$.

5. Peraturan Pemerintah Nomor 103 Tahun 2014 tentang Pelayanan Kesehatan Tradisional.

6. Badan Penelitian dan Pengembangan Kesehatan Kementrian Kesehatan RI. Riset kesehatan dasar 2013.

7. Badan Penelitian dan Pengembangan Kesehatan Kementrian Kesehatan RI. Riset kesehatan dasar 2018.

8. Constitution of the World Health Organization 1946.

9. International Bioethics Committee. Report of the IBC on traditional medicine systems and their ethical implications. Paris: UNESCO; 2013.

10. Peraturan Menteri Kesehatan Nomor 15 Tahun 2018 tentang Penyelenggaraan Pelayanan Kesehatan Tradisional Komplementer

11. Undang-undang Nomor 20 Tahun 2013 tentang Pendidikan Kedokteran.

12. Peraturan Menteri Kesehatan Republik Indonesia Nomor 1787/MENKES/PER/ XII/2010 tentang Iklan dan Publikasi Pelayanan Kesehatan.

13. Undang-undang Nomor 5 Tahun 2017 tentang Pemajuan Budaya. 